\title{
HISTORY AND THE MOVIES: SOME THOUGHTS ON USING FILM IN CLASS
}

\author{
John Leazer \\ Carthage College
}

Hollywood movies about historical topics often present a dilemma for history instructors. On one hand, movies are a powerful medium and, certainly, no student is immune to their effects. As such, they have the potential to be an extremely effective teaching tool. On the other hand, movies have many flaws that can make them particularly challenging as instructional material. For the most part movies rarely, indeed if ever, depict history correctly. Thus, many instructors argue that movies usually do more damage than good and cannot possibly be used in any serious history class. To use film, one must balance the interest that students often have in the movies against the challenges associated with their use. Achieving that balance is not impossible. Based on my own experience, I would argue that instructors ignore film at their own peril. Moreover, when used correctly, movies can be effective in helping increase students' understanding of history and especially historiography.

Hollywood movie producers have long been fascinated with history. And who can blame them? Some of the most lucrative films ever made deal with historical themes. For example, the 1995 movie Braveheart chronicling the exploits of the legendary Scottish patriot, William Wallace, grossed over 210 million dollars. ${ }^{1}$ Even this staggering figure pales in comparison to the returns seen by the movie Titanic based on the doomed voyage of the Royal Mail Ship Titanic, which to date has grossed, incredibly, over two billion dollars. ${ }^{2}$ These two mega-blockbusters are just a small sample of countless other profitable historical movies.

Yet this success for Hollywood presents a problem for instructors of history in the classroom. History teachers know that many movies rarely if ever "get it right." There can be no better example of this than Braveheart, which aside from its five Oscars, including Best Picture, should have also received an award for a historical movie that gets almost all of its history wrong. Examples of the movie's historical inaccuracies are too numerous to list, but one of the most glaring infractions is the depiction of one of Wallace's greatest military victories, the Battle of Stirling Bridge. In the movie, there is no bridge to be found. Instead, the battle is staged in a wide, open field. The end result is a visually awesome battle scene, but one that is not at all accurate. Another glaring error in the film is the fanciful love affair between William Wallace and Isabella, the French wife of the future Edward II. Aside from the total improbability of such a scenario, Isabella was a little girl in France at the time of the

\footnotetext{
'Braveheart (1995), IMDb http://www.imdb.com/title/tt01 12573/.
}

${ }^{2}$ Titanic (1997), IMDb http://www.imdb.com/title/tt0120338/. 
supposed affair and did not marry Edward until two years after Wallace had been executed, thus making such an affair impossible.

Now certainly, historians expect a certain amount of, shall we call it, misinformation from Hollywood films. History instructors are not too naïve to realize that producers and directors will use their "creative license" to titillate modern audiences. But even so, some inaccuracies can throw historians over the edge. For example, during one scene in Braveheart, the evil English King Longshanks, that is Edward I, grants English noblemen land and privileges in Scotland, including the right of primae noctis, the right of the lord to take a newly married Scottish woman into his bed on her wedding night. Edward does this, as he maliciously states in the movie, in order to "breed" the Scots out of Scotland. Because of this scene in particular, a Scottish historian from my graduate school days would just about have an aneurysm whenever the topic of Braveheart came up. The thought of the general public believing that this blatant misrepresentation of history was accurate was too much for him to even consider.

What is worse is that many movies-again Braveheart is a good example--spend a fortune on making their movies as elaborate in scale and as realistic as possible. This gives many movies an appearance of legitimacy. It is laudable that producers will at times go to great pains to accurately portray certain elements of their films such as making sure that their costumes and sets are as historically authentic as possible. However, they then often have their characters do things that no one at the time would have ever done or say things that no one would have ever said. This is when films are the most dangerous since these elaborate spectacles about serious topics may convince many movie goers that this is accurate history.

So if the historical accuracy of films cannot be trusted, then how can movies be at all helpful in the classroom? For one thing history instructors must keep in mind that, as the earnings of Braveheart and Titanic indicate, the American public flocks to these movies. There is no stopping them. As a result, whether instructors like it or not, most students have acquired at best an incomplete and often incorrect impression of history. However, my appeal for the use of movies as a teaching tool is not a "we can't beat them so we might as well join them" argument. There are three important reasons why incorporating movies in the classroom can, in fact, be a positive experience.

First, movies can get students interested in history as nothing else can. The power of film is truly remarkable. When I was growing up in the Chicago area, the local TV station, WGN, had a program on Sundays called Family Classics that featured a "classic" movie. Many of these movies had historical themes. I used to sit entranced in front of the TV watching films like Captain Blood, a 1930s swashbuckler starring Errol Flynn that takes place during the Monmouth Rebellion and the Glorious Revolution against King James II, or The Sea Hawk, another Errol Flynn swashbuckler 
that takes place during the reign of Elizabeth $\mathrm{I}^{3}$ As a youngster, I had no idea who James II and the Duke of Monmouth were or what the Glorious Revolution was about. But these movies opened up a new world that resulted in many trips to the library. Even if most students are not that historically curious, it cannot be denied that historical movies are interesting to them and expose them to people, places, and times that they might never have known about.

Second, movies create common ground for discussion, a valuable link between the world of the instructor and the students. For example, a few years back I had just begun to talk about the reign of Henry VIII of England when a student's hand shot up in the air and she asked me if I had seen the miniseries The Tudors. At the time I had not, but many students in the class had and they all had various opinions about it. What impressed me the most at the time was that it created quite a buzz of energy. Because of their interest, I made a point of watching the first season of The Tudors. However, when I watched the opening preview, I almost had an aneurysm myself. While watching the steamy introductory trailer scenes, I read the blurb on the video jacket cover, which stated: "Henry VIII: young, sexy and the most powerful man in the world. The throne and the world became his at the age of nineteen."

How, I wondered, could so much wrong information be crammed into two short sentences? I understood why the producers might falsely claim that Henry was the most powerful man in the world in order to exaggerate his importance. But why would they claim that Henry was nineteen at his accession when he was actually seventeen? How could they get something as simple as that wrong?

However, I found that these inaccuracies, which were so offensive to me, are exactly why the trailer works so well in class. After I show it to the students, I read out loud the blurb on the jacket cover and ask them what they think. As for the claim that Henry was the most powerful man in the world, this is a great way to introduce England's place in the world compared to other European powers such as France and Spain, not to mention places outside of Europe such as China. As far as getting Henry's age wrong at his accession, all one has to do is watch the movie trailer and the reason is apparent. Simply stated, it is full of sex-it would not be proper today to have a seventeen-year old high schooler engaging in that type of behavior. At nineteen, Henry is of legal age, which is acceptable to modern audiences. What is most important is that the students get this right away. This simple exercise always gets students' full attention while also conveying important information.

Third and most important, including movies is a great way to make students aware that they have to analyze critically not only everything they read, but everything they see. I think one of the most important things that any instructor does is to teach

${ }^{3}$ Captain Blood (Warner Bros., 1935) and The Sea Hawk (Wamer Bros., 1940).

${ }^{4}$ The Tudors: The Complete First Season, DVD (Showtime Networks Inc., 2007). 
students how to analyze the world around them in a critical way. As historians, we should give our students the tools they need to analyze the written word. But I also think that critical analysis of what they see is just as important, especially when it relates to history. A great example of this comes from Walt Disney's animated movie Pocahontas. ${ }^{5}$ In the opening scene, we see John Smith onboard a ship on the way to the New World. The movie then switches to Pocahontas' village and shows the daily lives of the Native Americans. I show this opening clip and then ask students how the Native Americans are depicted in this scene. Students point to their peaceful lifestyle and never fail to recognize that the Native Americans are shown to be civilized. Yet they never usually get what I am after and I have to repeat my question. How are the Native Americans depicted? That is, how are they actually drawn by the animators? Only once in awhile do I get a student who notices what I am talking about. The answer, of course, is that the Native Americans are in great physical shape. With their rippling muscles they look like they just came out of a gym. Even Pocahontas' elderly father has an abdominal "six pack." I ask students how the Europeans were drawn in the earlier scene. Except for the hero John Smith and his faithful sidekick, they mostly all had sagging bellies, five o'clock shadows, and were swilling beer as they contemplated killing Indians while their own leader plotted against them. Whether or not these depictions are right or wrong, good or bad, it is important that students recognize what is being presented.

Now having said all of this, there are several challenges that instructors must overcome in order to make movies a successful part of the classroom experience. The first and most important challenge is to not get bogged down in how correct the historical details of any movie are. Of course, no film gets everything right. Many people, instructors included, like to point out and argue about what the movies got right and wrong. Indeed, even the History Channel a few years back would show a historical movie and then, during the commercial breaks, have one or two historians and a moderator discuss the film's errors. This can be a lot of fun and can serve as a way to start a discussion like The Tudors example clearly shows. But aside from being fun, these types of discussions do not have a lot of value in the classroom. Thus, my main suggestion is to not make historical errors in films the focal point of any discussion. What is far more important is for students to recognize the historical interpretation that the movie portrays. Ultimately, most people do not know and do not really care what Braveheart got right and wrong. But you can be sure that they will remember the film's overall interpretation of Anglo/Scottish relations. That is, that the Scottish were innocent victims and the English were the evil aggressors. You can bet that the Errol Flynn movies mentioned above did not get much history right, but they had a definite interpretation of the personalities of King James II and Elizabeth I.

${ }^{5}$ Pocahontas (The Walt Disney Company, 1995). 
These interpretations - some obvious and some more subtle-are the most useful aspect of using film in the classroom, since they often are based on contemporary views and even historical scholarship. By pointing this out, movies can introduce students to historiography and many significant historiographical debates without much trouble. For example, in the relatively unknown comedy Yellowbeard, the English Queen Anne is played quite unflatteringly by a portly Peter Bull in drag, giving an exaggerated view, yet one based on contemporary accounts and later historians, of Anne's lack of ability. ${ }^{6}$ In contrast modern historians such as Edward Gregg and Robert Bucholz have done much to rectify this image by pointing out Queen Anne's overlooked qualities and successes. ${ }^{7}$ Thus this film clip sets up a nice discussion on the debate about the effectiveness of Queen Anne's reign. How deeply I plunge into the historiographical debate depends on the level of the class. In survey courses I usually just mention the debate. In upper-level courses I assign more sophisticated readings from primary and secondary sources to facilitate a more specific discussion.

Another example that illustrates this point that I use in class comes from The Private Life of Henry VIII, a 1933 black-and-white film starring Charles Laughton as Henry. ${ }^{8}$ In one scene Henry barges in on a group of ladies-in-waiting when Anne Boleyn is about to be executed. He immediately becomes enamored with a young Katherine Howard who is present and during their following short conversation he gives Katherine a particularly leering glance, foreshadowing his future relationship with her. The scene is historically inaccurate for a number of reasons, but that is really incidental. With this one glance Laughton gives the impression that Henry's fondness for so many wives is based on his ego and insatiable sexual appetite. This, of course, is in opposition to Robert Shaw's portrayal of Henry in A Man for All Seasons, which depicts a Henry VIII that was forced to change wives for political and religious reasons. ${ }^{9}$ Aside from a discussion on the personality of Henry, I find this an excellent way to introduce students to the debate on whether the English Reformation was a grassroots phenomenon or imposed from the top down. In more advanced classes, this introduction leads to readings from A.G. Dickens' traditional account of the Reformation, which depicts a corrupt church that was ripe for reform, to the revisionist

\footnotetext{
${ }^{6}$ Yellowbeard (Orion Pictures, 1983). For a contemporary account of a negative view of Queen Anne, see Sarah Jennings Churchill Marlborough, Private Correspondence of Sara, Duchess of Marlborough (London: Henry Colburn, Publisher, 1838; 1972 reprint edition), vol. ii, 110-116. For a more modern view, see Norah Lofts, Queens of England (New York: Doubleday \& Company, Inc., 1977), 140-141.
}

${ }^{7}$ Edward Gregg, Queen Anne (London: Routledge \& Kegan Paul, 1980); Robert Bucholz, The Augustan Court: Queen Anne and the Decline of Court Culture (Stanford: Stanford University Press, 1993).

${ }^{8}$ The Private Life of Henry VIII (United Artists, 1933).

${ }^{9}$ A Man for All Seasons (Columbia Pictures, 1966). 
works of Christopher Haigh and Eamon Duffy, which depict an English population that was satisfied with the Catholic Church and thus had the Reformation forced upon them. ${ }^{10}$

A second challenge with using film in the classroom deals with time. Instructors should not give into the temptation of showing or talking about movies for the whole of a class or even for a substantial part of it. Most history classes barely have the time to fit in all the lectures, discussions, and tests let along show movies. That is how it should be. A quality history course is not a film class, nor should it be. Film must be used sparingly, as a tool that opens a discussion or introduces or enhances a lecture but does not dominate. Thus, watching full-length films is out of the question and would dumb down a serious history class. Only carefully edited sections from movies should be used. For example, my introduction to Henry VIII only consists of a few short clips and thus does not take much time.

The last challenge deals with what films an instructor should use. This is a problem with no easy solution, since it requires a significant amount of time to wade through an endless amount of historical movies in order to find the one that will enhance exactly what is being taught in class. Once that is done, more time is needed to edit out the right few minutes that are most useful. In addition many historical movies, even though they deal with the topic that you are covering, do not lend themselves to be used easily in class. Once I started using film in class, I found that when I now watch movies, I am always on the lookout for something I can use in class. Also, I have found that it is useful to use anything that students are familiar with themselves. Movies such as The Private Life of Henry VIII that no student has heard of can work well, but it is always better to use recent films that they would have seen, or, like the Disney film, ones that they would have seen growing up. Ultimately, of course, the instructor can only use what he or she is familiar with. This means that as conscientious instructors, we are forced to go out and do our homework and watch more movies!

\footnotetext{
${ }^{10}$ A.G. Dickens, The English Reformation (New York: Schocken Books, 1964); Eamon Duffy, The Stripping of the Altars: Traditional Religion in England c. 1400-c.1580 (New Haven: Yale University Press, 1992); Christopher Haigh, English Reformations: Religion, Politics and Society under the Tudors (Oxford: Clarendon Press, 1993).
} 